Jurnal Bimbingan Konseling
$10(2)(2021): 69-64$
UNNES

\title{
The Effectiveness of Rational Emotive Behavior Therapy Counseling to Increase Self Esteem of Slow Learner Children
}

\author{
Devi Nurshobah ${ }^{1 凶}$, Awalya Awalya ${ }^{2}$, Sunawan Sunawan ${ }^{2}$ \\ 1. SMP Negeri 15 Cirebon, Indonesia \\ ${ }^{2}$ Universitas Negeri Semarang, Indonesia
}

\begin{tabular}{l}
\hline Article Info \\
\hline History Articles \\
Received: \\
13 January 2021 \\
Accepted: \\
19 February2021 \\
Published: \\
30 August 2021 \\
\hline Keywords: \\
self esteem; Single \\
Subject; Rational \\
Emotive Behavior \\
Therapy Counseling
\end{tabular}

\begin{abstract}
One of the measures to accommodate the learning needs of slow learner students is as a form of support for the inclusion paradigm in schools. Learning that is attempted by the teacher is an effort to condition slow learner students according to their learning needs. The purpose of this study was to test the effectiveness of Rational Emotive Behavior Therapy counseling to increase the Self Esteem of Slow Learner Children in Inclusion Schools SMP Negeri 15 Cirebon. To achieve such objective, the study used single subject design with the pattern of multiple baselines across individuals done in eleven sessions of observation, namely 3 baseline A1 sessions, 5 times intervention session, and 3 baseline A2 sessions. For more, the subjects of this study were two indicated experiencing self esteem. In this state, behavior target was reduced from self esteem behavior. Meanwhile, the data of the observed subjects were collected thorough direct observation method with Goal Attainment Scale guides. Further, visual graph analyses were carried out to look for mean, the degree of level of performance, rapidity behavior change, the trend of performance, stability levels, and overlap data which were then followed by $\mathrm{T}$ score and $\mathrm{z}$ score calculations. The results showed that Rational Emotive Behavior Therapy counseling was able to increase self esteem. For further research, you can use a reversal design pattern so that it can be seen about the comparison of the two baseline conditions before and after the intervention so that the effect of consistent behavior change in the intervention phase can be revealed more deeply.
\end{abstract}

\footnotetext{
Correspondence address:

J1. Pasuketan No.19, Lemahwungkuk, Kec. Lemahwungkuk, Kota

Cirebon, Jawa Barat 4511

p-ISSN 2252-6889

E-mail: devygood25@gmail.com

e-ISSN 2502-4450
} 


\section{INTRODUCTION}

Problems that often arise in slow learner children are their lack of interest in education, low achievement motivation and even hate school (Al-Mighwar, 2006). First, adolescents whose parents have unrealistic high aspirations of academic or social achievement that continue to push to achieve the desired goals. Second, adolescents who are less accepted by classmates, who do not experience the joy of classmates in various activities. Third, adolescents who mature earlier are physically much bigger than their classmates, because their appearance is older than their actual age, they are often expected to perform better than their abilities. The three types of adolescents who are less interested in education usually show characteristics of their displeasure. For example, underachieving, working below his ability in every subject or in a subject he doesn't like, skipping classes. Symptoms like this are often seen in those who have low self-esteem.

Self-esteem is one of the most important elements of personality in influencing the social and psychological qualities of an individual (Coopersmith, 1967: 1). One of the reasons it is important to understand self-esteem is to help individuals learn things.

Coopersmith (1967: 4) defines self-esteem as an individual's assessment of himself to be maintained, part of which comes from the individual's interaction with the environment and from the amount of appreciation, acceptance, and attention from others he receives. There are two categories of self-esteem, namely high self-esteem (positive) and low selfesteem (negative). Ideally, individuals have high self-esteem because it is closely related to the future. Orth and Robins (2014) state that high self-esteem affects success and well-being in life domains such as social relationships, work, and health. A similar statement was put forward by Waitley (1997: 76) in his book entitled "Psychology of success: developing your selfesteem" that the individual's self-esteem will contribute to the achievement of goals in academic success, career and personal happiness. Given the evidence that self-esteem has important consequences in the real world, the development of self-esteem needs special attention.

Low self-esteem problems if allowed to drag on will have an impact on individual psychology, such as depression and anxiety. Sawislo and Ulrich (2013). prove the relationship between self-esteem with depression and anxiety. The same thing is also stated by Saleh (1988) that individuals who have high selfesteem generally believe in their own abilities, are realistic, optimistic and effective in dealing with their problems, so they rarely experience adjustment disorders, including psychological disorders such as depression.

Based on interviews with three grade VIII students of SMP Negeri 15 Cirebon which is also the only inclusive school in the city of Cirebon, it shows that those with low self-esteem scores are dominated by slow learner children, this shows that they often find it difficult to adapt to their surroundings because considers himself inappropriate and unfit to be friends with others. Difficult to accept their own condition and tend to want their life like other people who are considered more fortunate than themselves.

One intervention that can be applied to deal with students' self-esteem problems is through counseling using a rational emotive behavior therapy approach. Based on the results of research conducted by Tripamungkas (2013), rational emotive behavior therapy group counseling can increase self-esteem for class XIIPS 4 students at SMA Negeri 1 Nganjuk is rational emotive behavior therapy counseling. Low self-esteem will lead to various conflicts, both intrapersonal and interpersonal conflicts that originate from the individual's own cognition and emotions. Therefore, through individual counseling using an approach rational emotive behavior therapy is expected to help individuals to be able to change irrational thinking to become rational. Banks \& Zionts (2008) states that irrational beliefs are a significant cause of emotional disorders such as anxiety, guilt, anger, and depression. 
Rational emotive behavior therapy counseling teaches how to change irrational beliefs into rational ones so that individual emotions and behavior become better and functional. Another assumption that supports the use of rational emotive behavior therapy counseling approach to increase students' self esteem is as stated by Darminto (2007) that specifically rational emotive behavior therapy counseling can be applied effectively to deal with various cognitive, emotional and behavioral difficulties related to psychological and psychopathology. . Based on these considerations, the researcher intends to test the effectiveness of rational emotive behavior therapy counseling to increase students' selfesteem.

Self esteem is also closely related to how to think, use feelings and behave. Therefore, the Rational Emotive Behavior Therapy (REBT) approach is suitable for use in problems of self esteem. REBT or rational emotive behavior therapy counseling was developed by Albert Ellis, an existentialist in 1955 as well as an American clinical psychologist. The general goal of rational emotive behavior therapy counseling is to help individuals identify their irrational belief systems and modify them in order to be more rational. The counseling focuses on efforts to help individuals learn to acquire skills that make it easier for them to form more rational thoughts, lead to greater self-acceptance and happiness and encourage the ability to enjoy life more. Therefore, providing rational emotive behavior therapy counseling intervention can be used to handle this case.

In research it was found that the use of rational emotive behavior therapy counseling is very suitable in dealing with the problem of low self-esteem. Students who experience low selfesteem can directly be handled through counseling services with a rational emotive behavior therapy approach so that irrational thoughts that cause negative judgments about themselves can be changed or replace them with rational thoughts so that they can generate positive assessments on them. self-esteem increased. Self esteem is also closely related to how to think, use feelings and behave Therefore, in guidance and counseling there is a Rational Emotive Behavior Therapy (REBT) approach which is very suitable for use in this problem. REBT or emotive behavior rational counseling developed by Albert Ellis, an existentialist in 1955 as well as an American clinical psychologist.

Seeing the basic purpose of rational emotive behavior therapy counseling is to teach how individuals change their emotional dysfunctional behavior and behavior healthy personality through training in rational thinking. This goal is in line with the concept of the goal of Islamic-based counseling, which is to teach how individuals empower their potential, namely fithrah which is related to faith (faith) to develop and function properly.

\section{METHODS}

The subjects of this study were two students in grades VII and IX in the Inclusion School of SMP Negeri 15 Cirebon. who are indicated to experience low self-esteem. Both have 14 years of age who are female. This research was conducted using a single subject design pattern multiple design across individuals. The instrument used in this study is GAS (Goal Atttainment Scaling) to provide a measure of change that is individualized by the criteria. There are three objectives of the GAS scale (Goal Attainment Scaling). First, verbally can regulate and control behavior and other people give recognition for their abilities more than 3 times from 4 people they know. Second, verbally believes' and believes in his physical deficiencies and tries his best to explore his physical strengths, more than 3 times out of 4 people he knows. Third, verbally trusting and trusting friends, other family members, and vice versa, the person also shows self-acceptance and appreciates him more than 2 times than the 4 people he knows. Collecting data in this study is direct observation for three

thematic subject hours using the GAS (Goal Attainment Scaling) procedure. 
This study uses interrater reliability to display the reliability of the research data. The interrater reliability coefficient obtained is 0.829 .

This single subject research procedure consists of 3 steps. First, baseline A1, which measures the tendency toward self-esteem before being given intervention for 3 sessions for 40 minutes. Second, the treatment stage (intervention stage) for 4 sessions, namely; relationship building (realtion building), cognitive stage (management of thoughts and views), emotive and affective management stage, behavior management stage. The third stage is the A2 baseline phase, which is to repeat the process like the first baseline phase, which is three sessions. Data analysis was carried out using visual graphic analysis by taking into account the average, level of performance, trends of performance, the percentage of data overlap, and the rapidity of behavior change. Then the $\mathrm{T}$ score and the $\mathrm{z}$ score are calculatedThe subjects of this study were two students in grades VII and IX in the Inclusion School of SMP Negeri 15 Cirebon. who are indicated to experience low self-esteem. Both have 14 years of age who are female. This research was conducted using a single subject design pattern multiple design across individuals. The instrument used in this study is GAS (Goal Atttainment Scaling) to provide a measure of change that is individualized by the criteria. There are three objectives of the GAS scale (Goal Attainment Scaling). First, verbally can regulate and control behavior and other people give recognition for their abilities more than 3 times from 4 people they know. Second, verbally believes' and believes in his physical deficiencies and tries his best to explore his physical strengths, more than 3 times out of 4 people he knows. Third, verbally trusting and trusting friends, other family members, and vice versa, the person also shows self-acceptance and appreciates him more than 2 times than the 4 people he knows. Collecting data in this study is direct observation for three thematic subject hours using the GAS (Goal Attainment Scaling) procedure.

This study uses interrater reliability to display the reliability of the research data. The interrater reliability coefficient obtained is 0.829 .

This single subject research procedure consists of 3 steps. First, baseline A1, which measures the tendency toward self-esteem before being given intervention for 3 sessions for 40 minutes. Second, the treatment stage (intervention stage) for 4 sessions, namely; relationship building (realtion building), cognitive stage (management of thoughts and views), emotive and affective management stage, behavior management stage. The third stage is the A2 baseline phase, which is to repeat the process like the first baseline phase, which is three sessions. Data analysis was carried out using visual graphic analysis by taking into account the average, level of performance,

trends of performance, the percentage of data overlap, and the rapidity of behavior change. Then the $\mathrm{T}$ score and the $\mathrm{z}$ score are calculated.

\section{RESULTS AND DISCUSSION}

GAS data results displayed the mean of all the five scales. For more, based on the three session of baseline $A 1$, the mean of the five scales of GAS showed -1.37 and the mean value of SD was 0.65 . It had the highest number of 1.67 and the lowest number of -1.33 . Next, in five sessions of intervention (B), the total mean of those scale was 1.22 , and the mean of SD was 0.81 . It had the highest number of 1.4 , and the lowest was 1.2. After that, the baseline A2 session showed that the total mean of the five scales of GAS was 1.60, and the mean of SD was 0.58 . Its highest number was 1.67 , and the lowest was 1.33 . For the details, the following table 1 shows the description of GAS data. 
Table 1. The Description of GAS (Goal Attainment Scaling) Results Data

\begin{tabular}{llllllll}
\hline \multirow{2}{*}{$\begin{array}{l}\text { GAS } \begin{array}{l}\text { Sales } \\
\text { anxiety) }\end{array} \\
\end{array}$} & (social & Subjects & \multicolumn{2}{l}{ Conditions } \\
\cline { 3 - 8 } & & & \multicolumn{2}{l}{ InselineA1 } & \multicolumn{2}{l}{ BaselineA2 } \\
\cline { 3 - 8 } & & Mean & SD & Mean & SD & Mean & SD \\
\hline Scale 1 & AN & -1.33 & 0.58 & 1.2 & 0.84 & 1.67 & 0.58 \\
Performance self-esteem & UN & -1.33 & 0.84 & 1.2 & 0.84 & 1.33 & 0.58 \\
\hline Scale 2 & AN & -1.67 & 0.58 & 1.2 & 0.84 & 1.67 & 0.58 \\
Physically self-esteem & UN & -1.00 & 1.00 & 1.4 & 0.55 & 1.67 & 0.58 \\
\hline Scale 3 & AN & -1.33 & 0.58 & 1.2 & 0.84 & 1.67 & 0.58 \\
Social self-esteem & UN & -1.33 & 0.58 & 1.2 & 0.84 & 1.67 & 0.58 \\
\hline Total Mean & & $\mathbf{- 1 . 3 7}$ & $\mathbf{0 . 6 5}$ & $\mathbf{1 . 2 2}$ & $\mathbf{0 . 8 1}$ & $\mathbf{1 . 6 0}$ & $\mathbf{0 . 5 8}$ \\
\hline
\end{tabular}

The analyses results of changes in the five scales of GAS can be seen in Figure 1. The scale of communication initiation showed that the trend of performance of $\mathrm{AN}$ and $\mathrm{UN}$ was ascending (ascending trend) in the second session. However, in the third session, they had flat trend of performance (no trend). For more, the density of behavior appearance (rapidity behavior change) in every behavior observation session happened to always increase except in the second and third sessions. In addition, AN and $\mathrm{UN}$ in the baseline level gained the range stability level of $66.67 \%$. In the intervention phase (B), $\mathrm{AN}$ and $\mathrm{UN}$ had flat trend of performance (no trend) in the fifth and sixth sessions. For more, the density of behavior appearance (rapidity behavior change) in AN was assumed to ascend except in the fifth and seventh sessions. Next, the range stability level of $\mathrm{AN}$ and $\mathrm{UN}$ in the intervention phase was $40 \%$. Also, the baseline A2 phase of AN and UN showed the descending trend of performance (descending trend) in the ninth session. It meant that the density of behavior appearance (rapidity behavior change) occurred in every session after the intervention, unless in the ninth session. Further, AN in the phrase of baseline A1 gained $66.67 \%$ and $33.33 \%$ for UN.

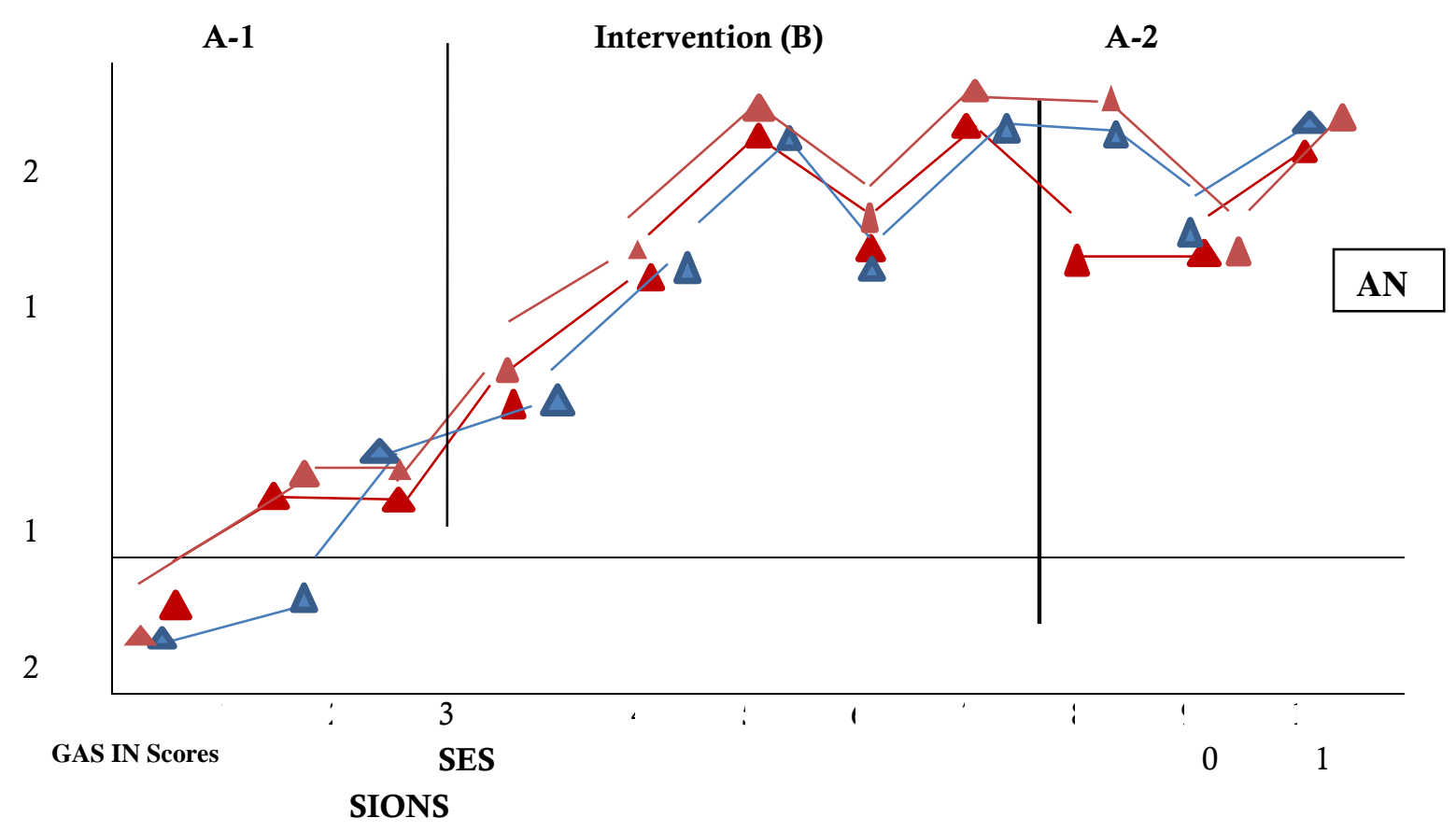




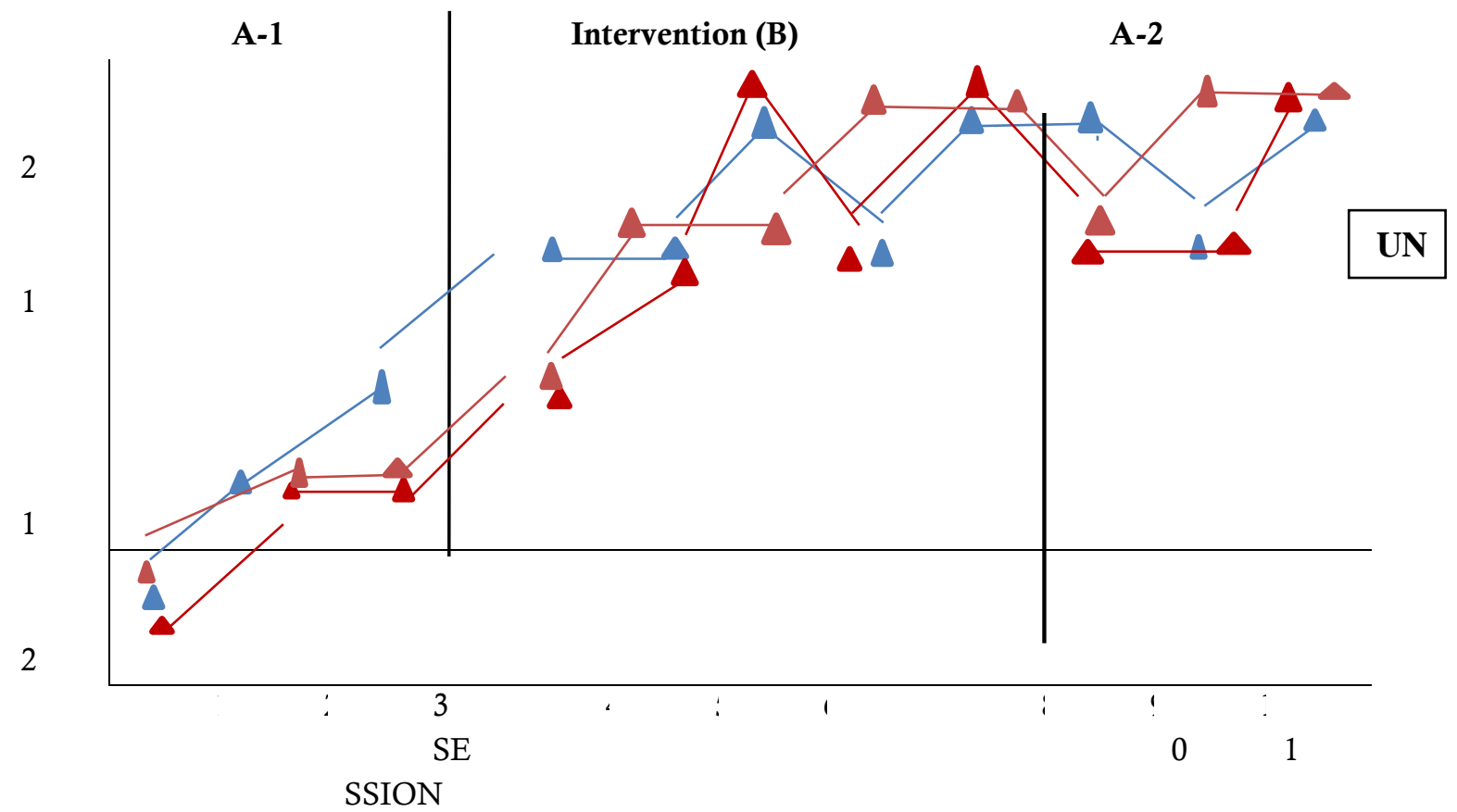

Figure 1. The Analysis of Visual Baseline A1, Intervention B, Baseline A2 related to Social Anxiety in $\mathrm{AN}$ and $\mathrm{UN}$

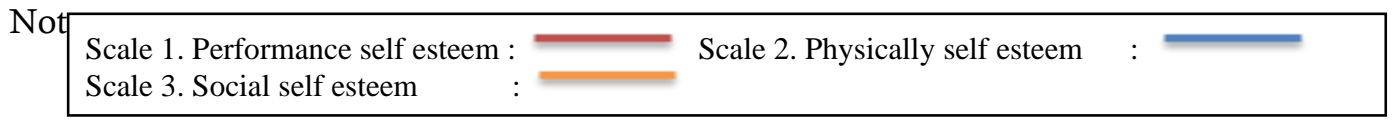

Furthermore, the visual analysis on the scale of the performance self esteem showed in Figure 1 revealed that the trend of performance of $\mathrm{AN}$ and $\mathrm{UN}$ was ascending in the second session. However, in the third session, the trend of performance tended to be flat (no trend). The density of the appearance of behavior (rapidity behavior change) occurred in every behavior observation session tended to increase except in the second and third observation sessions. Again, AN and UN in the baseline phase had the range stability level of $66.67 \%$. In the intervention phase (B) SY and IN tended to have flat trend of performance (no trend) in the fifth and sixth sessions. The density of behavior appearance (rapidity behavior change) in AN happened to increase except in the fifth and seventh intervention sessions. Further, the range stability for $\mathrm{AN}$ and $\mathrm{UN}$ in the intervention phase was $40 \%$. In baseline phase $\mathrm{A} 2, \mathrm{AN}$ and UN showed descending trend of performance in the ninth session. This meant that the density of behavior appearance (rapidity behavior change) occurred in each session after the intervention except in the ninth session. On the on hand, SY in the baseline phase A2 had the range stability level of $66.67 \%$ and $33.33 \%$ in IN.

The scale of physically self esteem flat the trend of performance (no trend) in the first and second sessions. Furthermore, in the third session, the trend of performance tended to be an ascending trend. Meanwhile, IN was seen to have ascending trend in the second and third session. Hence, the density of the appearance of behavior (rapidity behavior change) occurred in each time the observation session of behavior tended to increase except in the second session. Furthermore, the baseline phase A1 in both the AN and UN had range stability level of $33.33 \%$. Whereas, in the intervention phase (B), SY had flat trend of performance (no trend) in the fifth and sixth sessions. This meant that the density of 
the appearance of behavior (rapidity behavior change) tended to increase except in the seventh intervention session. Furthermore, the AN condition in the intervention phase had the range stability level of $40 \%$ and $60 \%$ for IN. Next, in the baseline phase A2, AN showed descending trend of performance in the ninth session, while UN showed descending trend of performance in the ninth session. Thus, the density of the appearance of behavior (rapidity behavior change) occurred in every session after the intervention except in the eleventh session. It had the range stability level of $33.33 \%$ to both $\mathrm{AN}$ and UN.

Visual analysis on the scale of social self esteem in the AN and UN based on Figure 1 showed that the trend of performance tended to be the ascending. This meant that the density of the appearance of behavior (rapidity behavior change) occurred in every observation session tended to rise except in the second session. Furthermore, AN and UN in the A1 baseline phase had the range stability level of $66.67 \%$. Whereas, in the intervention phase (B) the results of the visual analysis on $\mathrm{AN}$ and $\mathrm{UN}$ had ascending trend of performance in the first and second sessions. Thus, the density of the appearance of behavior (rapidity behavior change) tended to rise except in the seventh session. Again, AN in the intervention phase had the range stability level of $66.67 \%$ and $40 \%$ for UN. Meanwhile, in the baseline phase A2, $\mathrm{AN}$ indicated descending trend of performance. In conclusion, the density of the appearance of behavior (rapidity behavior change) occurred in every session after the intervention except in the tenth session which has improvement. Furthermore, AN in the baseline phase A2 had the range stability level of $40 \%$ and $33.33 \%$ for IN.

The percentages overlap of the five GAS scales (Goal Attainment Scaling) in the research subjects can be seen in Figure 1. The percentage overlap results from the A1 baseline to the intervention were $0 \%$. The percentages were obtained because there were no data points on the intervention conditions that overlapped the range of data points in the baseline A1 condition. Meanwhile, the percentage of overlap from the intervention to baseline A2 from the five GAS scales was $60 \%$. Next, it came to the calculation of $\mathrm{T}$ score and $\mathrm{z}$ score of the results of the GAS score (Goal Attainment Scaling) on the five scales. The results of the $\mathrm{T}$ and $\mathrm{z}$ score of the AN and UN subjects can be seen in Table 2. 
Tabel 2. The Description of the Data of Goal Attainment Score (T) Results on AN and UN Subjects

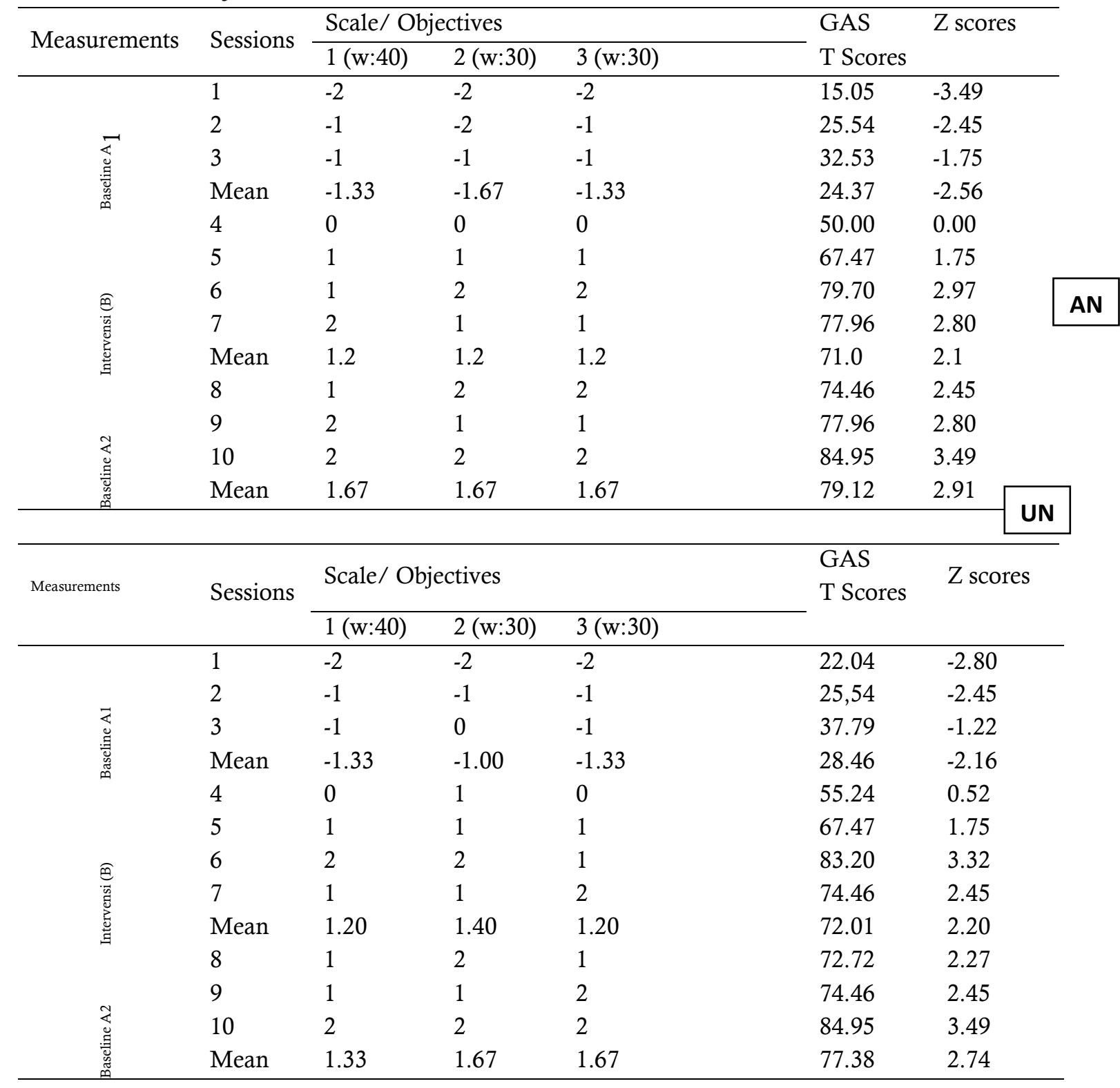

In the intervention (B) on $\mathrm{AN}$ showed a significant change seen from the mean of $\mathrm{T}$ score which was initially 24.37 in the intervention condition (B) became 71.0 with the improvement on the mean of $\mathrm{z}$ score from -2.56 to 2.1 with the difference of 4.66 . It can be concluded that there was a significant change because the value was more than 1.96 . Meanwhile, in the baseline condition A2 the AN subject experienced an improvement in the mean of $\mathrm{T}$ score of the intervention (B) from 71.00 to 79.12 and the $\mathrm{z}$ score which originally 2.1 from intervention (B) became 2.91 with a difference of 0.81 . It can be concluded that there was no significant change because it was less than 1.96 .

In the intervention (B) IN showed that there was a significant change seen from the mean of $\mathrm{T}$ score which was originally 28.46 in the intervention condition (B) became 72.01 with an mean of $\mathrm{z}$ score which increased from 2.16 to 2.20 with the difference of 4.36 . It can be concluded that there was a significant change since the score was more than 1.96 . Furthermore, in the A2 IN baseline conditions there was an improvement in the mean of $\mathrm{T}$ 
score of the intervention (B) of 72.01 to 77.38 and the $\mathrm{z}$ score which initially obtained the score of 2.20 from intervention (B) changed to 2.74 with a difference of 0.54 . It can be concluded that there was no significant change because it was less than 1.96 .

This study aims to determine the increase in self-esteem of slow learner students in the inclusion school SMP N 15 Cirebon against the three GAS (Goal Attention Scaling) scales which are target behaviors carried out through Rational Emotive Behavior Therapy (REBT) counseling. The GAS (Goal Atttainment Scaling) scale consists of; self-esteem scale of work performance (performance self-esteem), physical self-esteem (physically self-esteem) and social self-esteem (social self-esteem). The findings of the study indicate that Rational Emotive Behavior Therapy counseling is effective in increasing the self-esteem behavior of slow learner students

The results of this study indicate that Rational Emotional Behavior Therapy (REBT) counseling can increase the self-esteem of slow learner students. The Rational Emotive Behavior Therapy approach provides an individual understanding to be more confident in their own behavior. Schematically, REBT counseling is the determination of the indications of thoughts and behavior. Then the stable schematic of Rational Emotive Behavior Therapy is the influence of the belief centesis in the individual. The REBT approach at the implementation stage is expected that individuals can think positively and control their positive thoughts in the hope of being able to increase students' self-esteem. This is reinforced by the results of a case study by Ariestiria (2016: 34) which shows that REBT counseling is used for slow learner students who have low selfesteem, although not all changes directly. And the subject is taught how when faced with stimuli that make the subject of low self-esteem, to oppose negative thoughts into positive thoughts towards others.

This study successfully confirmed that Rational Emotive Behavior Therapy (REBT) counseling was effective in increasing the self- esteem of slow learner students. The increase in self-esteem seen from the two research subjects showed a sharp change in mean (average) from the baseline phase A1, intervention (B), and baseline A2, both the level of performance that showed large changes, no overlap data, rapidity behavior change, the emergence of behavior that tends to meeting and fast, and the trend of performance which from the baseline phase increases to decrease in the intervention phase. The results of this study are relevant to previous research conducted by Elsherbiny (2015: 89) which measures the effectiveness of REBT interventions in increasing self-esteem. The results show the significance of REBT in providing intervention for people who have low self-esteem.

Based on the results of the research that has been done, it was found that the provision of intervention in the form of Rational Emotive Behavior Therapy was effective in increasing the self-esteem of slow learner students in inclusion schools experienced by the subject. Self-esteem is also closely related to how to think, use feelings and behave. Therefore, in guidance and counseling there is a Rational Emotive Behavior Therapy (REBT) approach which is very suitable for use in this problem. REBT or behavioral emotive rational counseling developed by Albert Ellis, an existentialist in 1955 as well as an American clinical psychologist. The general purpose of rational emotive behavior therapy counseling is to help individuals identify irrational belief systems and modify them to become more rational. The counseling focuses on efforts to help individuals learn to acquire skills that make it easier for them to form more rational thoughts, lead to greater self-acceptance and happiness and encourage the ability to enjoy life more.

\section{CONCLUSION}

Based on the results of visual graphic analysis using the mean, level of performance, rapidity behavior change, data overlap, and trend of performance of each target behavior, it 
can be seen that target behavior increases selfesteem contained in the GAS (Goal Attainment Scaling) scale can be achieved by optimal. So it can be concluded that REBT counseling is considered effective for increasing self-esteem of inclusive students at SMP N 15 Cirebon.

School counselors can use REBT counseling to overcome self-esteem in both students who have special needs in inclusive schools. As for further research, if you want to examine behavior modification using REBT counseling, the hope is to use a reversal design pattern so that it can be seen about the comparison of two baseline conditions before and after the intervention so that the consistent effect of behavior change in the intervention phase can be revealed more deeply.

\section{REFRENCES}

AC. Dahlan. (2009). Bimbingan dan Konseling Islami; Sejarah, Konsep dan Pendekatannya. Yogyakarta: Pura Pustaka.

Albano, A.M., \& Kendall, P.C. (2002) Cognitive Behavioural Therapy for Children and Adolescents with Anxiety Disorders: Clinical Research Advances. International Review of Psychiatry, 14, 129-134. Doi: 10.1080/095402.

Alberto \& Troutman. (2006). Applied Behavior Analysis for Teachers. Colombus: Merrill American Psychiatric Association, Diagnostic and Statistical Manual of mental disorders, Washington DC: American Psyciatric Association, 2000, 4th ed. Text revision

Antony, M.M. \& Swinson, R.P. (2000). Shyness $\&$ Social Anxiety Workbook. Canada: New Harbinger Publications, Inc.

APA, A. P. (2013). Diagnostic and Statistical Manual of Mental Disorder. Washington, DC: American Psychiatric Publishing.

Arikunto, S. (2006). Prosedur Penelitian Suatu Pendekatan Praktik. Jakarta: Rineka Cipta.

Aunillah, Fi, dan Maria Goretti Adiyanti. (2015). Program Pengembangan
Keterampilan Resiliensi untuk Meningkatkan Self-esteem pada Remaja." Gadjah Mada Journal of Professional Psychology 1.1

Azwar, Saifuddin. (2013). Validitas dan Reliabilitas Ed.4. Yogyakarta: Pustaka Pelajar.

Barlow \& Hersen. (2011). Single Case Experimental Designs. Canberra: Pergamon Press.

Beck, A.T' (1979). Cognitive Therapy and The Emotional Disorders. Boston: Meridian, Penguin Books, Ltd.

Cakiroglu, O. (2012). Single subject research: Applications to Special Education. British Journal of Special Education. Published by Blackwell Publishing Ltd, 9600 Garsington Road, Oxford OX4 2DQ, UK and 350 Main Street, Malden, MA 02148. USA. $\quad$ Doi: $\quad 10.1111 /$ j.14678578.2012.00530.x.

Carlson, J. Sperry, L. Lewis, J.A, (2005). Family Therapy Techniques: Integrating and Tailoring Treatment, New York: Routledge.

Corey, G. (2013). Pendekatan Kasus Konseling dan Psikoterapi (8 ed.). Belmont, CA: Brooks / Cole, Cengage Learning.

Craighead, L.W., Craighead, W.E., Kazdin, A.E., \& Mahoney, M.J. (1994). Cognitive and Behavioral Iinterventions. Boston: Allyn and Bacon.

Creswell, John. (2015).Riset Pendidikan.Yogyakarta: Pustaka Pelajar.

Efendi, Muhammad. (2006). Pengantar Psikopedagogik Anak Berkelainan. FKIP UNS: Surakarta.

Fletcher, J.M Morris, R.D \& Lyon, G.R, Classification and definition of Learning Disability. In Swanson, H.L. Haris, K.R, \& Graham, S (Eds). (2003). Hanbook of Learning Disability(pp.30-56), New York: The Guilford Press.

Fransiska Kumalasari. (2009). "Efek Terapi Rational Emotive Behaviour (REB) Terhadap depresi pada NAPI Wanita", Tesis. (Semarang: Program Pascasarjana 
Universitas Katolik Soegijapranata, 2009).

Grebb, J. A., Kaplan, H. I., \& Sadock, B. J. (2010). Sinopsis Psikiatri Ilmu Pengetahuan Perilaku Psikiatri Klinis Jilid Dua. Tangerang. Binarupa Aksara.

Hallahan, D. P., \& Kauffman, J. M. (2006). Exceptional Learners: An Introduction to Special Education, 10 th ed. USA: Pearson Education, Inc.

Hammond, D. \& Gast, D.L. (2010). Descriptive Analysis of Single Subject Research Design: 1983-2007. Education and
Training in Autism and Developmental Disabilities. 45 (2), 187-202. Dapat diunduh https://pdfs.semanticscholar.org/f611/f8 000f89b15fd996373411c9844d20ac5154.p df.

Hanin Hamjah, Salasiah. (2018). Pendekatan Da'wah Al-Irsyad Al-Nafsiyy Menurut Al- Ghazali: Satu Kajian Di Pusat Kaunseling Majlis Agama Islam Negeri Sembilan [BP190. 5. C8 S161 2008 f rb]. Diss. Universiti Sains Malaysia. 